\title{
Model of Land Acquisition Productivity Performance for Toll Road Projects in Indonesia
}

\author{
Kartika Nur Rahma Putri ${ }^{1 *}$, Puti Farida Marzuki ${ }^{2}$ \\ ${ }^{1}$ Department of Civil and Environmental Engineering, Universitas Gadjah Mada, \\ Yogyakarta, 55284, Indonesia \\ ${ }^{2}$ Faculty of Civil and Environmental Engineering, Institut Teknologi Bandung, \\ Bandung, 40132, Indonesia \\ kartikanurrahmaputri@ugm.ac.id
}

Received 17-07-2020; accepted 04-08-2020

\begin{abstract}
Land acquisition process in the Indonesian toll road project has a high level of uncertainty. Several previous studies mainly discuss the risks involved in toll road projects and their mitigation measures, but the effect of existing risks on land acquisition scheduling is rarely reviewed. This research aims to develop a model for land acquisition productivity performance for toll road projects. The performance of productivity was modelled based on a predefined duration mentioned in Indonesian Act. No. 2/2012, compared to the actual duration from 6 toll road projects using Monte Carlo simulation. The validity of model was tested using the Section II of Cisumdawu Toll Road project. The simulation productivity result was $23.13 \mathrm{~km} / \mathrm{year}$, with a standard deviation of $6.704 \mathrm{~km} /$ year. Meanwhile, the actual productivity was $20.50 \mathrm{~km} / \mathrm{year}$, which was still within the range of the simulation's standard deviation. Hence, the models could reasonably describe the reality of the project. The most important activities that could affect land acquisition productivity performance were payment of compensation, the determination of compensation value, settlement of claims for the forms of compensation, and the identification and inventory of land ownership data.
\end{abstract}

Keywords: Risk modelling, Productivity performance, Land acquisition, Toll road, Monte Carlo

\section{Introduction}

Indonesia is in a period of development. The toll road project is one of the infrastructure projects that the government claims to improve the transportation and logistics distribution sector. Land acquisition, or eminent domain, creates the most obstacle in toll road development in Indonesia [1]. The high level of uncertainty in land acquisition time and cost complicates the project owner's attempt to determine any project risks. It makes the project financially unfeasible, hindering the government's efforts to actualize the toll road project as a publicly funded one.

In line with the statement above, [2] emphasize that land acquisition process has the highest risk during the project. After the construction, land and toll road are part of government's assets. While

Cite this as: Putri, K., \& Marzuki, P. (2020). Model of Land Acquisition Productivity Performance for Toll Road Projects in Indonesia. Civil and Environmental Science Journal (Civense), 3(2), 84-94. doi: https://doi.org/10.21776/ub.civense.2020.00302.3 
investors only have the rights to operate it during the concession period. The certainty of cost and duration of land acquisition is relatively low. Hence the risk of cost overrun, and delayed time of operation becomes high.

Since the regulation states that land acquisition falls under the authority of the government, every risk following the delay in land acquisition becomes the responsibility of the government as well. The regulation of land acquisition in Indonesia is issued in Act. No. 2/2012 on Land Acquisition for Land Acquisition for Development of Public Interest [3].

In construction projects, risks are inevitable. Risks that are not seriously addressed in the initial planning will result in a cost overrun and delay in project completion. Some previous studies mainly discuss the risks involved in toll road projects and their mitigation measures. Some main obstacle factors resulted from [4] were the application process for establishment of development sites (Surat Permohonan Penetapan Lokasi Pembangunan/SP2LP), the provision of residual land issues, and the delay in payment of compensation. Meanwhile, based on [5] the three dominant risk source variables in toll road projects land acquisition were (a) The planning stage where investors do not immediately complete administrative requirements $(6.2 \%)$; (b) the deliberation stage where complaints arise from the community $(5.9 \%)$; (c) and the occurrence of land problems $(5.6 \%)$.

Several researches have been focusing on risks on toll road projects. A study of risks analysis in Trans Sumatra Toll Road Project [6] revealed that land acquisition was the main factor contributing to toll road projects delay. While from [7] five main risk factors identified in this project are: licensing risk, feasibility study, detailed engineering design, land acquisition and investment. The result of the research depicted that land acquisition was one of major factors that could affect toll road project implementation. Unfortunately, the effect of existing risks on land acquisition productivity performance is rarely reviewed.

Thus, the aim of this study was to develop a model of land acquisition productivity performance to predict the duration for upcoming project. The source of this study includes seven schemes of land acquisition for toll road projects. The model can be used to determine the forecast value of land acquisition duration for the next projects. The results from this research were expected to provide a better understanding for both project owners and contractors to develop a better land acquisition schedule.

\section{Material and Methods}

This research focused on the process of land acquisition based on Act No. 2/2012 and conducted between September until December of 2016. Since most of the toll road projects had already completed land acquisition planning and preparation (i.e., two of the four phases listed in the regulation), this research only observed main activity in Phase III, namely the implementation of land acquisition. Subphases in each main activity is not observed due to lack of recording duration data in the field.

The first two steps of land acquisition process were done by using old regulation namely Presidential Regulation No. 65/2006 on Amendment of Presidential Regulation No. 36/2005 on Land Acquisition for Development of Public Interest [8]. The earlier regulation does not mention about the maximum duration of each phase in land acquisition process, thus the implementation in the field becomes long and protracted.

To generate a land acquisition productivity performance, the first step that needs to be done is to develop a Probability Density Function (PDF) of the duration of the land acquisition project from existing projects in Indonesia. The respondents included seven people from Commitment-Making official (Pejabat Pembuat Komitmen) for land acquisition toll road project in Indonesia. Two data collected from Toll Road Projects in Sumatra, and five data from Toll Road Projects in Java. Software fit distribution was used to generate the parameter of each PDF.

The second step was to perform a Monte Carlo simulation using @Risk software. This simulation was carried out to predict the performance of the duration of land acquisition in the next project. There is one project whose data will be compared with the results of the simulation to ensure that the results 
of the modelling can represent the actual conditions. The results of the both stages will be analysed to obtain conclusions from this study.

\subsection{Regulation of Land Acquisition for Development of Public Interest}

It should be mention time and place of research in first part. All materials and methods that used such chemical for analysis, treatment and experimental design must be stated clearly and briefly. State the objectives of the work and provide an adequate background, avoiding a detailed literature survey or a summary of the results. A Theory section should extend, not repeat, the background to the article already dealt with in the Introduction and lays the foundation for further work. a Calculation sections represents a practical development from a theoretical basis.

To accelerate the process of land acquisition for public infrastructure development-including toll road projects, the government issues a regulation containing the maximum duration for each phase of land acquisition. The regulation is Act. No. 2/2012 on Land Acquisition for Development of Public Interest. The process contains the following four phases:

Phase I: Land Acquisition Planning

- Feasibility study

- The establishment of land acquisition planning document

Phase II: Land Acquisition Preparation

- Initial data collection (60 days)

- Public consultation (118 days)

- The settlement of claims for compensation (107 days)

Phase III: Land Acquisition Implementation

- The identification and inventory of land ownership data (79 days)

- The determination of compensation value (90 days)

- Settlement of claims for the forms of compensation (102 days)

- Payment of compensation (35 days)

Phase IV: The Delivery of Land Acquisition

- The National Land Authority submits the land acquisition result to the Ministry of Public Works (7 days)

- Land certification (30 days)

Each sub-phase has their own break-down explained in the regulation. Although the maximum duration of land acquisition has been regulated, there are still many delays in the field. Land Acquisition is influenced by several factors, namely information dissemination process and community's knowledge and legal awareness of a public project and the firm legal basis for its implementation [9].

\subsection{Monte Carlo Simulation}

Monte carlo simulation was chosen to develop a duration model because in the implementation of land acquisition process, there are some uncertainty resulted from its own procedures and parties involved. This distribution is more realistic to describe uncertainty in risk analysis.

Monte Carlo simulation illustrates risk analysis by generating models of possible outcomes by replacing any factors that have inherent uncertainty with a range of values obtained from a Probability Density Function (PDF). The probability density function is based on the data collection of the probability of occurrence for each factor. In this research, the PDF was built from the data of actual duration to finish each step-in land acquisition process from several of sample projects.

The calculation to predict the upcoming duration of project is processed by selecting a random value from the probability density function. It calculates the results over and over-using different random value. The iteration can involve hundreds or even thousands of calculations. The simulation assigns a new probability density function to every possible outcome. 


\subsection{Data Processing}

\subsubsection{Generate Probability Density Function (PDF)}

Probability Density Function is needed as a basic value to perform the Montecarlo simulation. To generate PDF, the primary data obtained from the questionnaire were as follows:

- The time of the commencement of land acquisition

- The percentage of completed land acquisition using the old regulation (i.e. Presidential Regulation No. 65/2006)

- The percentage of completed land acquisition using the new regulation (i.e. Act No. 2/2012)

- The duration of each activity (as listed in the new regulation) that had been implemented in the field.

- The obstacles experienced in implementing the new regulation.

In this land acquisition, the scheduling was developed by modelling every phase as a series of activities. In other words, the relationship between the activities was Finish to Start (FS) as seen in figure 3. This method was based on the laws and regulations that provided a serial time limits for each activity. The actual duration or sequence may vary (as long as it complies with the regulation) based on the field. The source of uncertainty modelled in this study was the performance of the four activities in the implementation phase captured in Figure 1.

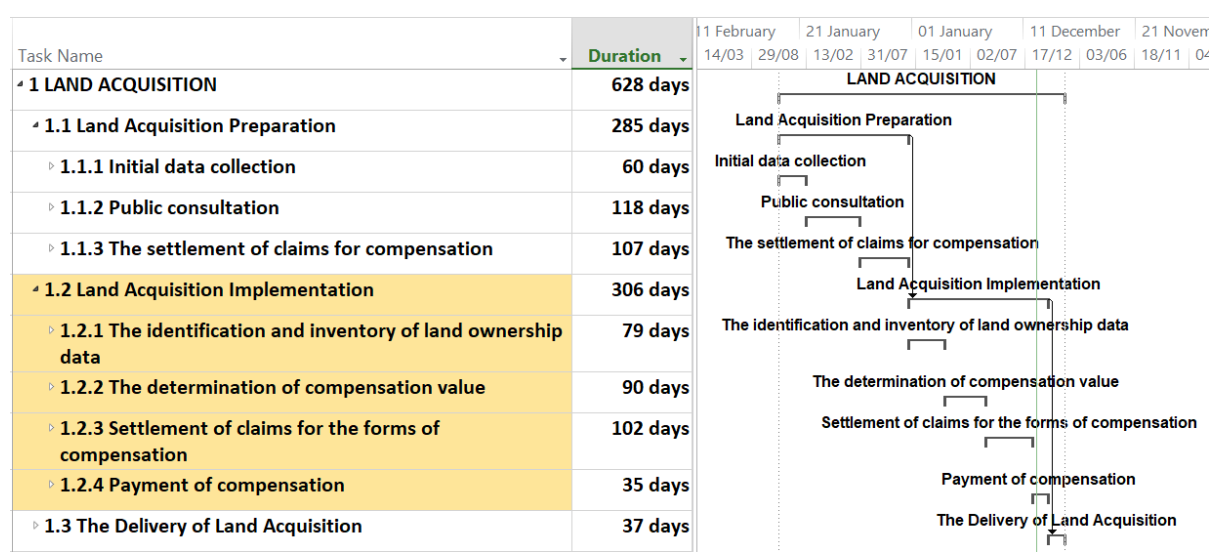

Figure 1. The Model of Land Acquisition Duration for the Main Activities

The data obtained from the interview were processed for data distribution using the fit distribution software. This step was applied to produce the performance distribution values of the four activities in the phase of land acquisition implementation for further analysis. A larger set of project data would create a better and more representative distribution.

The length of land to be acquired is different for each project, yet the maximum time duration in the regulation is the same. Hence, to make a model using different data from several projects, there should be a new variable that can show general comparison. In this study, productivity defined as 'the speed of the team in conducting land acquisition, presented in $\mathrm{km} / \mathrm{year}$ '. As mentioned above, some projects still use the old regulation to accomplish their land acquisition process. Thus, in this research, there were a variable namely planned productivity which compared the remaining length of land that had not been acquired vs maximum duration allowed in Act No. 2/2012. While actual productivity was defined as a comparison between the length of land that had been acquired using new regulation vs actual duration to acquired it. Meanwhile, the land acquisition performance compares the completion time of actual land acquisition with the completion time planned. All data mentioned below were collected in September until December 2016.

$$
\begin{aligned}
& \text { Planned Productivity }(P P)=\frac{\text { The remaining lenght of land }(\mathrm{km})}{\text { Maximum duration allowed according to Act No.2/2012(year) }} \\
& \text { Actual Productivity }(A P)=\frac{\text { The length of land acquired according to Act No.2 } / 2012(\mathrm{~km})}{\text { The actual duration in the field (year) }}
\end{aligned}
$$




$$
\text { Land Acquisition Performance }=\frac{\text { Actual Productivity }}{\text { Planned Productivity }} \times 100 \%
$$

An example of calculation will be presented to illustrate the steps that had been done in this study. A summary of maximum duration allowed according to Act No. 2/2012 can be seen in Figure 1. For project 1, the data obtained from interview were as follow:

Phase: Identification and inventory of land ownership data

- Planned duration (see Figure 1): 79 days

- Take an assumption that number of working days in one year is 20 days per month $\times 12$ month $=$ 240 days

- Total Length of toll road: $54,8 \mathrm{~km}$

- Length acquired using old regulation: 7,7 km (14,05\% from total length)

- Remaining length to be acquired with new regulation: $54,8 \mathrm{~km}-7,7 \mathrm{~km}=47,11 \mathrm{~km}$

- Planned Productivity (see equation 1)

$$
\mathrm{PP}=\frac{47,11 \mathrm{~km}}{\frac{79 \text { days }}{240 \text { days }} \times 1 \text { year }}=143,1 \mathrm{~km} / \text { year }
$$

Until the data were taken, the performance of land acquisition duration was as follows:

- The length of land acquired using new regulation: $24,55 \mathrm{~km}$

- Actual duration to complete the process: 134 days

- Actual Productivity (see equation 2)

$$
\mathrm{AP}=\frac{24,55 \mathrm{~km}}{\frac{143 \text { days }}{240 \text { days }} \times 1 \text { year }}=43,97 \mathrm{~km} / \text { year }
$$

Thus, the land acquisition performance was:

- Land acquisition performance (see equation 3)

$$
\frac{43,97 \mathrm{~km} / \text { year }}{143,1 \mathrm{~km} / \text { year }}=\mathbf{3 0 , 7 3} \%
$$

\begin{tabular}{|c|c|c|c|c|c|c|}
\hline & \multirow[b]{2}{*}{ Project Name } & \multicolumn{4}{|c|}{ Land Acquisition Performance (\%) } & \multirow[b]{2}{*}{ Average } \\
\hline & & $\begin{array}{l}\text { Identification } \\
\text { and inventory of } \\
\text { land ownership } \\
\text { data }\end{array}$ & $\begin{array}{l}\text { Determination } \\
\text { of } \\
\text { compensation } \\
\text { value }\end{array}$ & $\begin{array}{l}\text { Settlement of } \\
\text { claims for the } \\
\text { forms of } \\
\text { compensation }\end{array}$ & $\begin{array}{l}\text { Payment of } \\
\text { compensation }\end{array}$ & \\
\hline 1 & Project 1 & $30.73 \%$ & $72.16 \%$ & $26.58 \%$ & $36.48 \%$ & $41.49 \%$ \\
\hline 2 & Project 2 & $60.40 \%$ & $67.57 \%$ & $85.00 \%$ & $49.44 \%$ & $65.6 \%$ \\
\hline 3 & Project 3 & $85.58 \%$ & $100.17 \%$ & $82.88 \%$ & $59.24 \%$ & $81.97 \%$ \\
\hline 4 & Project 4 & $52.32 \%$ & $72.00 \%$ & $127.5 \%$ & $106.06 \%$ & $89.47 \%$ \\
\hline 5 & Project 5 & $28.30 \%$ & $25.80 \%$ & $26.18 \%$ & $34.39 \%$ & $28.67 \%$ \\
\hline 6 & Project 6 & $4.63 \%$ & $8.19 \%$ & $5.18 \%$ & $14.23 \%$ & $8.06 \%$ \\
\hline \multicolumn{2}{|c|}{ Average } & $43.66 \%$ & $57.65 \%$ & $\mathbf{5 8 . 8 9 \%}$ & $49.97 \%$ & \\
\hline
\end{tabular}

These formulas were used to calculate the land acquisition performance of six projects at every implementation phase. The calculation results are mentioned in Table $\mathbf{1 .}$

Table 1. Data of land acquisition performance to be plotted in Probability Density Function (PDF) 
The obtained value from the calculation of the land acquisition performance was plotted. The data then being processed with best fit software to determine the type of distribution for each activities using software fit distribution. The Probability Density Function (PDF) is summarized in Table 2.

Table 2. The Probability Density Function of every activity in the phase of land acquisition

\begin{tabular}{lll}
\hline Activity & Probability Density Function & $\begin{array}{l}\text { Type of } \\
\text { Distribution }\end{array}$ \\
& Parameter \\
\hline
\end{tabular}

The identification and inventory of land ownership data

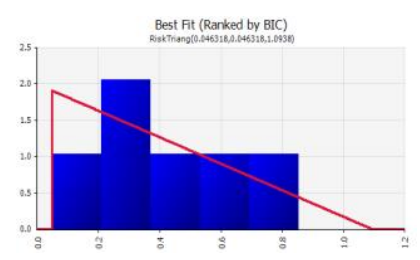

Left

Triangular $\quad 2^{\text {nd }}$ Parameter (Most Likely) (a) :

(ramp 0.0463

down) $\quad 3^{\text {rd }}$ Parameter (Maximum) (b) :

1.0938

The

determination of compensation value

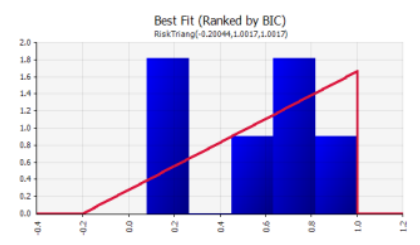

Right

Triangular

$1^{\text {st }}$ Parameter (Minimum) (a) : 0.20044

$2^{\text {nd }}$ Parameter (Most Likely) (b):

$3^{\text {rd }}$ Parameter (Maximum) (b) :

1.0017

Settlement of claims for the forms of compensation
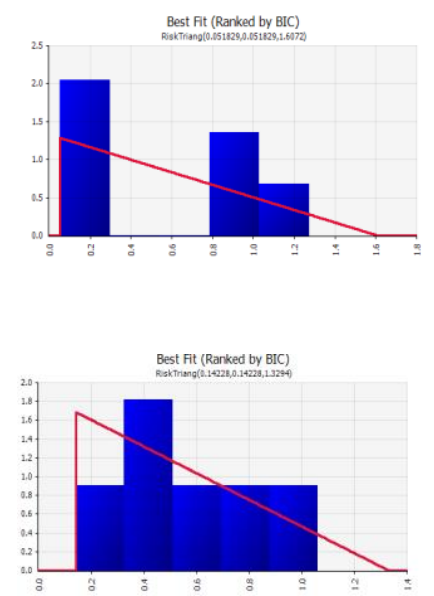

Left

Triangular $\quad 2^{\text {nd }}$ Parameter (Most Likely) (a) :

(ramp

down)

$1^{\text {st }}$ Parameter (Minimum) (a) :

0.051289

0.051289

$3^{\text {rd }}$ Parameter (Maximum) (b) :

1.6072

$1^{\text {st }}$ Parameter (Minimum) (a) :

Left

0.14228

Triangular $\quad 2^{\text {nd }}$ Parameter (Most Likely) (a) :

(ramp $\quad 0.14228$

down) $\quad 3^{\text {rd }}$ Parameter (Maksimum) (b) :

1.3294

\subsubsection{Monte Carlo Simulation}

The Monte Carlo simulation was performed after the distribution data of each activity was obtained using @Risk software. In this study, the source of uncertainty is the productivity performance of each activity. The planned productivity is a fixed value according to the actual project data. This simulation aimed to determine the performance of the land acquisition duration for each activity. This information was obtained by taking a random value that was included in the data distribution acquired previously. A land acquisition project was selected as an input for the simulation. This project was the toll road connecting Cileunyi, Sumedang, and Dawuan (Cisumdawu) Phase 2. The input data for simulation is Planned Productivity (PP). Planned productivity was calculated using equation (3) based on the Cisumdawu project data.

The total productivity from the simulation was compared with the actual productivity of the Cisumdawu Toll Road Project for further analysis. If the value of the former approached the latter, then 
the simulation would be concluded as proper and representative of the value in the field. The input for the Montecarlo simulation is listed in Table 3.

Table 3. The input for the Monte Carlo simulation

\begin{tabular}{llllll}
\hline Activities & $\begin{array}{l}\text { Planned } \\
\text { Productivity } \\
(\mathrm{km} / \text { year })\end{array}$ & $\begin{array}{l}\text { Performance } \\
(\%) \\
(\text { triangular })\end{array}$ & $\begin{array}{l}1^{\text {st }} \\
\text { Paramet } \\
\text { er }\end{array}$ & $\begin{array}{l}2^{\text {nd }} \\
\text { Paramet } \\
\text { er }\end{array}$ & $\begin{array}{l}3^{\text {rd }} \\
\text { Paramet } \\
\text { er }\end{array}$ \\
\hline $\begin{array}{l}\text { The identification and inventory of land } \\
\text { ownership data }\end{array}$ & 8.96 & 0.395 & 0.046 & 0.046 & 1.094 \\
$\begin{array}{l}\text { The determination of compensation value } \\
\begin{array}{l}\text { Settlement of claims for the forms of } \\
\text { compensation }\end{array}\end{array}$ & 7.87 & 0.601 & -0.200 & 1.002 & 1.002 \\
\begin{tabular}{l} 
Payment of compensation \\
\hline
\end{tabular} & 6.94 & 0.570 & 0.052 & 0.052 & 1.607 \\
\hline
\end{tabular}

When the simulation was run, the software would choose one random value based on the performance distribution (PDF) of each activity. The iteration was performed 10,000 times, and the result was a normally distributed risk output graph, as seen in Figure 2. This figure illustrates the land acquisition productivity performance.

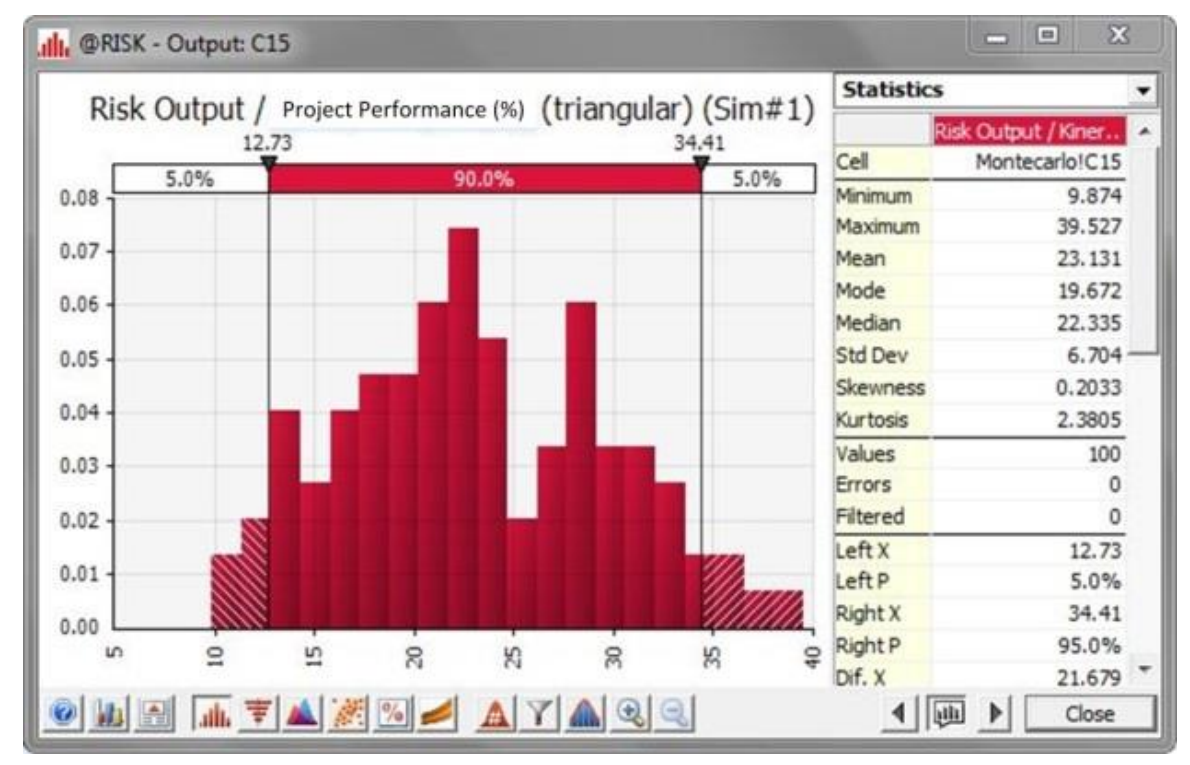

Figure 2. The Results of the Monte Carlo Simulation

Result parameter from simulation were listed below.
- Minimum
: $9.874(\mathrm{~km} /$ year $)$
- Maximum
: $39.527(\mathrm{~km} / \mathrm{year})$
- Mean
$: 23.131(\mathrm{~km} /$ year $)$
- Std. Deviation
: $6.704(\mathrm{~km} /$ year $)$
- Median
: $22.335(\mathrm{~km} / \mathrm{year})$

The tornado diagram showed the extent to which an alternative value could shift due to a certain change in the quantity. The bars in the diagram represented the payoff range if a specific quantity (variable) was given a variation from one end to another in the relevant range by retaining all variables in their base values. The tornado diagram of the simulation is displayed in Figure 3 below. 


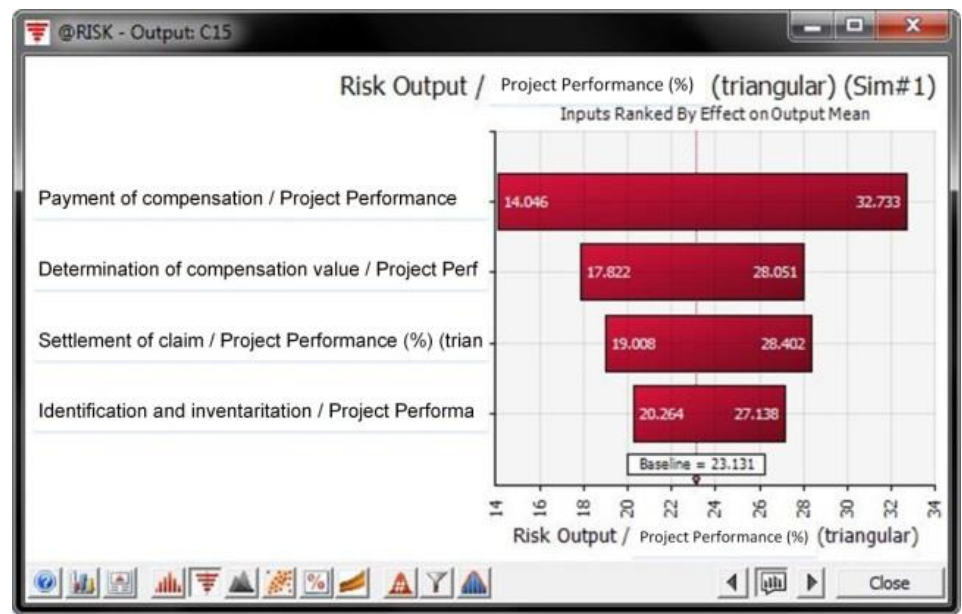

Figure 3. The Tornado Diagram of the Monte Carlo Simulation Results

The most influential activities in this simulation are presented in the following sequence.

1. Payment of compensation (in the form of money)

2. The determination of compensation value

3. Settlement of claims for the forms of compensation

4. The identification and inventory of land ownership data

This order shows that if the performances of the activities above are not good, it will likely influence the performance of the total project. Thus, payment of compensation and the determination of compensation value are two most critical activities that need to give more attention.

\subsubsection{Validation and Simulation Result}

To validate or identify whether the performed simulation could represent the actual value, this research compared the productivity of the simulated land acquisition with the actual productivity. The simulation value obtained from multiplication between Simulation Mean $(23.131 \mathrm{~km} / \mathrm{year})$ and percentage of each activity from total duration presented in Table 2 . While actual productivity obtained from interview data. The comparison can be seen in the Table 4.

Table 4 Comparison of Actual and Simulation Productivity

\begin{tabular}{|c|c|c|c|c|c|c|}
\hline \multirow{3}{*}{ Activities } & \multirow{2}{*}{$\begin{array}{l}\text { Planned } \\
\text { Productivity } \\
\text { (km/year) }\end{array}$} & \multirow{2}{*}{$\begin{array}{l}\text { Productivity } \\
\text { Weight }\end{array}$} & \multicolumn{2}{|c|}{$\begin{array}{c}\text { Simulation } \\
\text { Productivity (km/year) }\end{array}$} & \multirow{2}{*}{$\begin{array}{c}\text { Actual } \\
\text { Productivity } \\
\text { (km/year) }\end{array}$} & \multirow{2}{*}{$\begin{array}{l}\text { Difference } \\
(\mathrm{km} / \text { year })\end{array}$} \\
\hline & & & Total & $\begin{array}{c}\text { Each } \\
\text { Activity }\end{array}$ & & \\
\hline & (a) & $(c)=(a) /(b)$ & (d) & $\begin{array}{c}(\mathrm{e})=(\mathrm{c}) / \\
(\mathrm{d})\end{array}$ & (f) & $\begin{array}{c}(\mathrm{g})=(\mathrm{f})- \\
(\mathrm{e})\end{array}$ \\
\hline $\begin{array}{l}\text { The identification and } \\
\text { inventory of land } \\
\text { ownership data }\end{array}$ & 8.96 & $20.37 \%$ & & 4.71 & 4.9 & -0.19 \\
\hline $\begin{array}{l}\text { The determination of } \\
\text { compensation value }\end{array}$ & 7.87 & $17.88 \%$ & & 4.14 & 4.63 & -0.49 \\
\hline $\begin{array}{l}\text { Settlement of claims for } \\
\text { the forms of } \\
\text { compensation }\end{array}$ & 6.94 & $15.78 \%$ & 23.131 & 3.65 & 2.81 & 0.84 \\
\hline $\begin{array}{l}\text { Payment of } \\
\text { compensation }\end{array}$ & 20.23 & $45.98 \%$ & & 10.63 & 8.16 & 2.47 \\
\hline Total (b) & 43.09 & & & 23.13 & 20.50 & 2.63 \\
\hline
\end{tabular}


The simulation productivity was $23.13 \mathrm{~km} / \mathrm{year}$ with a standard deviation of $6.704 \mathrm{~km} / \mathrm{year}$. Meanwhile, the actual productivity was $20.50 \mathrm{~km} /$ year, which was still within the range of the standard deviation of the simulation productivity. This finding shows that the simulation results can represent the actual activities.

Observing the simulation results, the research was able to estimate the time required for completing the project with a predetermined probability and a certain confidence level (\%). The simulated value was the performance value. A higher performance value provided an assumption that the project ran very fast (optimistic). Yet in the land acquisition work, the confidence level value will be higher if the productivity plan is low. Therefore, a little modification to the percentile value was necessary. The value of $90 \%$ became a confidence level of $10 \%$, and $80 \%$ meant a confidence level of $20 \%$, and so forth, the illustration can be seen in Figure 4. Therefore, the percentage in this simulation made more sense, as seen in Table 5.

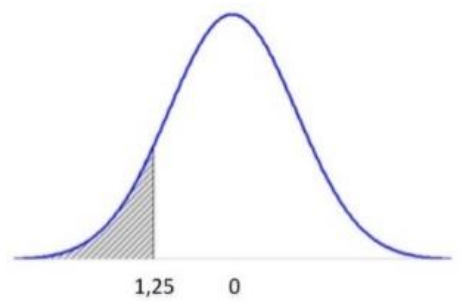

Figure 4 Area of $90 \%$ confident level in land acquisition productivity performance

Table 5 Standard Distribution Table for the Simulation

\begin{tabular}{ccc}
\hline Percentile & $\mathrm{z}_{\mathrm{x}}$ & $\begin{array}{c}\text { Forecast Value } \\
\text { Productivity } \\
\text { (km/year) }\end{array}$ \\
\hline $0 \%$ & 1.95 & 36.20 \\
$10 \%$ & 1.25 & 31.51 \\
$20 \%$ & 0.84 & 28.76 \\
$30 \%$ & 0.53 & 26.68 \\
$40 \%$ & 0.25 & 24.81 \\
$50 \%$ & 0 & 23.13 \\
$60 \%$ & -0.25 & 21.46 \\
$70 \%$ & -0.53 & 19.58 \\
$80 \%$ & -0.84 & 17.50 \\
$90 \%$ & -1.25 & 14.75 \\
$100 \%$ & -1.95 & 10.06 \\
\hline
\end{tabular}

For example, the calculation used to identify the project performance with a confidence level of $90 \%$ is as follows. Probability: $\mathrm{P}\left(\mathrm{z}<\mathrm{z}_{\mathrm{x}}\right)=90 \%$;

Based on the normal standard distribution table, $\mathrm{P}\left(\mathrm{z}<\mathrm{z}_{\mathrm{x}}\right)=90 \%$ has $\mathrm{z}=-1.25$

$$
\begin{aligned}
z_{x}= & \frac{x-\text { mean }}{\text { Standard Deviation }} \\
-1,25= & \frac{x-23.131}{6.704} \\
& x=14.751 \mathrm{~km} / \text { year }
\end{aligned}
$$

The table shows that the confidence level affects the confidence in the performance of land acquisition duration. The value of $14.751 \mathrm{~km} / \mathrm{year}$ can be used as a forecast value of land acquisition 
implementation process with confidence level of $90 \%$. The value of productivity for each level of confidence can be seen in Table 5 .

\section{Result and Discussion}

There were some facts reveals from the study above. According to Table 1, the number of average duration implementation for each activity varied from $43.66 \%$ up to $58,89 \%$, the range of differences was not too high. It means that each activity's duration was mostly delayed for around $50 \%$ of the actual value determined by the regulation. Nevertheless, if we look forward to each project's average productivity performance, the variation is extremely high. For example, from $8.06 \%$ to $89.47 \%$ for Project 6 and Project 4 respectively. It means that there were considerable differences in the government's ability to resolve the land acquisition problem. Both projects were part of the National Strategic Project of Indonesia. However, the performance of two example projects was dramatically different can be caused by the different priorities of each project. The National Land Agency's capacity was not enough since they also work for some other projects at the same time. Because of this limitation, they probably choose the top priority project to be done first.

Based on interview and risk identification data, the main parties contributing to the risks are National Land Agency, District Court or Supreme Court, and Ministry of Public Works and Housing to guarantee the existence and distribution of compensation money. Public awareness of the importance of land acquisition for the public interest also needs to be improved to make it easier to cooperate in public consultation process. Several problems that are mentioned quite often arise in land acquisition process are the different priority of project, the availability of compensation money, community participation, the limited resources of the National Land Agency, and time to complete the land acquisition claims in the District Court and Supreme Court.

The PDF of this research was able to run a simulation that can represent the actual value. By knowing the length of the road to be acquired and Planned Productivity, this simulation can help the government determine how many times needed to be allocated for the land acquisition process and become additional information on how to resolve the risk so that there is no delay in the predicted duration. If the duration seems too long, the government needs to pay more attention to the land acquisition project by giving an additional number of National Land Agency personnel, speeding up the settlement in the district and supreme court, and ensuring the disbursement of the fund. The focus of government plays a significant role in land acquisition projects.

The decision making to speed up the process of land acquisition falls under the authority of the project-determining party, which is the Head of the Commitment-Making Official for Land Acquisition in Toll Road project. This study provides new additional information, namely the probability of project success with specific percentiles in a specified duration. Nevertheless, project performance and completion remain dependent on the land acquisition implementation team in the field.

\section{Conclusions}

The number of average land acquisition productivity performance for each project shows an extremely big gap. This shows that some land acquisition activities could be completed very fast, and some are very slow for years. This depends on several problems that occur in the field such as the priority of project, the availability of compensation money, community participation, the limited resources of the National Land Agency, and time to complete the land acquisition claims in the District Court and Supreme Court. The duration of land acquisition depending on some main parties i.e. are National Land Agency, District Court or Supreme Court, and Ministry of Public Works and Housing.

The actual productivity for validation was still within the range of standard deviation from simulation productivity. This finding shows that the simulation results can represent actual activities. The value of Probabilistic Density Function (PDF) for each activity of land acquisition implementation can be used to forecast the duration of further projects. The most influential activities that could affect land acquisition productivity performance illustrated in tornado diagram was payment of compensation, the determination of compensation value, settlement of claims for the forms of compensation, and the 
identification and inventory of land ownership data respectively. Thus, the first and second activities need to get more attention from the government.

The data for this study obtained from 6 land acquisition for toll road projects during September until November of 2016. More additional data are needed to update the parameter of distribution (PDF) with current situation. The more data used, the better it will represent the actual condition.

\section{References}

[1] R. Z. Tamin, P. F. Marzuki, and S. F. Rostiyanti, "Complex and Uncertain Land Acquisition: One of Major Obstacles in Toll Road Public Private Partnership (PPP) Project in Indonesia," Internet J. Soc. Soc. Manag. Syst., vol. 7, no. 1, pp. 1-8, 2011.

[2] F. S. Sunito, "An Effort to Break Through the Toll Road Investment Barriers (In Bahasa)," in The-8th Indonesian National Conference on Road Engineering, 2007.

[3] The Government of Republic Indonesia, Indonesian Act. Number 2 of 2012 on Land Acquisition for Development of Public Interest. Indonesia, 2012.

[4] S. Sadono, "Analysis of Inhibitor Factors in Land Acquisition of Toll Road Projects," Master Thesis Report, Civil Engineering, Universitas Indonesia, 2007.

[5] A. Wibowo, A. Tjan, and A. Wibowo, "Analisis Resiko Pengadaan Tanah pada Proyek Pembangunan Jalan Tol," Master Thesis Report, Civil Engineering Program, Universitas Parahyangan, 2011.

[6] M. N. Karunia, "Analisis Risiko Keterlambatan Waktu Pada Proyek (Studi Kasus: Pembangunan Jalan Tol Trans Sumatera Bakauheni-Terbanggi Besar (Paket II Sidomulyo-Kotabaru Sta. 39+400 - Sta. 80+000) dan (Paket III Kotabaru-Metro Sta. 80+000 - Sta. 109+000))," Undergraduate Thesis, Civil Engineering Program, University of Lampung, 2016.

[7] A. Sandhyavitri and N. Saputra, "Analisis Risiko Jalan Tol Tahap Pra Konstruksi (Studi Kasus Jalan Tol Pekan Baru-Dumai)," J. Tek. Sipil, vol. 9, no. 1, pp. 1-19, 2019, doi: 10.28932/jts.v9i1.1366.

[8] The Government of Republic Indonesia, Presidential Regulation No. 65/2006 on Amandement of Presidential Regulation No. 36/2005 on Land Acquisition for Development of Public Interest. Indonesia, 2006.

[9] F. Hermawan, F. Kistiani, and T. D. Santoso, "Pengaruh Pembebasan Lahan Terhadap Risiko Proyek Konstruksi (Studi Kasus Social Engineering Proyek Jalan Tol Ruas Semarang Bawen)," TEKNIK, vol. 32, no. 2, pp. 88-94, 2011. 